\title{
PENGENDALIAN INTERN PADA PENERIMAAN DAN PENYALURAN \\ DANA ZAKAT, INFAQ, DAN SHADAQAH \\ PADA BADAN AMIL ZAKAT NASIONAL (BAZNAS) SULAWESI SELATAN
}

\author{
MUHAMMAD ADIL ${ }^{1^{*}}$ \\ 1Universitas Muhammadiyah Makassar \\ *muh.adil@unismuh.ac.id
}

\begin{abstract}
The purpose of this study is to find out the application of internal controls to the receipt and distribution of zakat, infaq, and sadaqah funds. The research method used is a qualitative method and the object of the research used is a procedure for the receipt and distribution of zakat, infaq, and sadaqah funds. This research looks at internal control, in the procedure for the receipt and distribution of zakat, infaq, and shadaqah funds at the South Sulawesi BAZNAS. The results showed that internal control and the receipt and distribution of zakat, infaq, and shadaqah funds at BAZNAS in South Sulawesi had some weaknesses but overall internal control had gone well.
\end{abstract}

Keywords: internal control, procedure system, revenue, expenditure.

\begin{abstract}
Abstrak
Tujuan dari penelitian ini adalah untuk mengetahui penerapan pengendalian internal terhadap penerimaan dan penyaluran dana zakat, infaq, dan shadaqah. Metode penelitian yang digunakan adalah metode kualitatif dan objek dari penelitian yang digunakan adalah sistem prosedur penerimaan dan penyaluran dana zakat, infaq, dan shadaqah. Penelitian ini melihat pengendalian internal, dalam sistem prosedur penerimaan dan penyaluran dana zakat, infaq, dan shadaqah pada BAZNAS Sulawesi Selatan. Hasil penelitian menunjukkan bahwa pengendalian internal dan atas penerimaan dan penyaluran dana zakat, infaq, dan shadaqah pada BAZNAS Sulawesi Selatan memiliki beberapa kelamahan namun secara keseluruhan pengendalian internal sudah berjalan dengan baik.
\end{abstract}

Kata kunci : pengendalian internal, sistem prosedur, penerimaan, pengeluaran

\section{PENDAHULUAN}

Kemiskinan adalah momok yang sangat ditakuti oleh setiap manusia. Krisis ekonomi yang melanda bangsa Indonesia pada akhir 1997 hampir meruntuhkan perekonomian yang telah dibangun berpuluh-puluh tahun. Dunia usahapun ikut limbung, tak kuasa menahan besarnya guncangan yang telah ditimbulkannya. Akhirnya banyak bidang usaha yang gulung tikar, dan Indonesia pun masuk dalam krisis ekonomi yang sangat dalam.

Menurut data Badan Pusat Statistik (BPS), menyatakan jumlah penduduk miskin Indonesia per Maret 2016 mencapai 28,01 juta orang, turun 0,50 juta dibandingkan September 2015 yang tercatat 28,51 juta orang. Jumlah penduduk miskin atau penduduk dengan pengeluaran per kapita per bulan di bawah garis kemiskinan di Indonesia mencapai 28.01 juta orang atau
10.86 \%. Selama periode September 2015Maret 2016, jumlah penduduk miskin menjadi 8,22 juta orang menjadi 7,79 juta orang. Sedangkan di daerah pedesaan kurang 0,22 juta orang dari 17,89 juta orang menjadi 17,67 juta orang pada maret 2016. Sehingga terjadi krisis moneter yang berakibat pada krisis ekonomi yang berkepanjangan yang dirasakan selama ini jika ditelusuri, salah satu penyebabnya adalah gaya hidup masyarakat yang materealistis. Gaya hidup semacam ini ditandai dengan kurangnya kepekaan nilainilai sosial dalam kehidupan masyarakat, yakni keanggenan masyarakat untuk berzakat, berinfak, dan ber-shadakah, hilangnya rasa $u k h u w a$, hilangnya solidaritas dan timbul kebathilan didalam diri.

Berbagai upaya yang dilakukan oleh pemerintah untuk mengentaskan 
kemiskinan namun belum berhasil, oleh karena itu Islam menawarkan salah satu solusi dengan mewajibkan umatnya untuk pemerintah dan pengeluaran kas yang memenuhi prinsip-prinsip pengendalian intern serta metode pencatatan yang baik yang dikenal dngan istilah Badan Amil Zakat (BAZ). BAZ adalah sebuah organisasi pengelolah zakat yang dibentuk oleh Pemerintah sebagai pelaksana amanat Undang-Undang Nomor No. 23 Tahun 2011 tentang pengelolaan Zakat.

LAZISMU melakukan pencatatan dan diakui sesuai dengan jumlah yang disalurkan kepada mustahiq, tetapi yang benar menurut PSAK 109 pada paragaraf 17 dan 29 bahwa, “ ZIS yang diakui sebagai pengurangan dana zakat sebesar jumlah yang diserahkan, jika dalam bentuk kas, jumlah tercatat, jika dalam bentuk aset nonkas. Tika Widiastuti dan Suherman Rosyidi (2015) meneliti tentang Model Pendayagunaan Zakat Produktif oleh Lembaga Zakat dalam Peningkatan Pendapatn Mustahiq. Menyatakan bahwa, melalui program PROSPEK (Program Sinergi Pemberdayaan Komunitas) PKPU berusaha memberdayakan ekonomi usaha kecil melaui kelompok suatu masyarakat.

Dengan melihat betapa pentingnya pengendalian intern, utamanya sistem prosedur penerimaan dan pengeluarannya, maka dilakukan penelitian pada BAZ agar dapat menentukan sistem prosedur penerimaan dan pengeluaran kas mana yang cocok untuk dipergunakannya.

\section{TINJAUAN PUSTAKA}

Pengertian zakat secara Etimologi, zakat adalah menyucikan, memperbaiki, berkembang, dan memuji. Zakat adalah berkembang, barakah, dan tambahan kebaikan. Zaka Al-Zuru'. Artinya tumbuhan berkembang. Zakat Al-Nafaqah, artinya yaitu nafkah itu diberi barakah.. Secara Terminologi, zakat merupakan nama sebagian dari sesuatu yang dikeluarkan dari harta atau badan dengan cara tertentu.
Pengertian zakat menurut dalam bukunya Zakat Dalam Sistem Hukum Pemerintahan Aceh (2016), Zakat adalah suatu kewajiban bagi umat Islam yang telah di tetapkan dalam Al-Qur'an, Sunnah Nabi dan Ijma parah ulama.

Penunaian zakat merupakan kewajiban bagi umat Islam yang mampu sesuai dengan syariat Islam. Zakat merupakan pranata keagamaan yang bertujuan untuk meningkatkan keadilan, kesejahteraan masyarakat, dan penanggulangan kemiskinan.

Dalam rangka meningkatkan daya guna dan hasil guna, zakat harus dikelola secara melembaga sesuai dengan syariat Islam, amanah, kemanfaatan, keadilan, kepastian hukum, terintegrasi, dan akuntabilitas sehingga dapat meningkatkan efektivitas dan efisiensi pelayanan dalam pengelolaan zakat. Selama ini pengelolaan zakat berdasarkan Undang-Undang Nomor 38 Tahun 1999 tentang Pengelolaan Zakat dinilai sudah tidak sesuai lagi dengan perkembangan kebutuhan hukum dalam masyarakat sehingga perlu diganti. Pengelolaan zakat yang diatur dalam Undang-Undang ini meliputi kegiatan perencanaan, pengumpulan,pendistribusian, dan pendayagunaan. Dalam upaya mencapai tujuan pengelolaan zakat, dibentuk BAZNAS yang berkedudukan di ibu kota negara, BAZNAS provinsi, dan BAZNAS kabupaten/kota.

BAZNAS merupakan lembaga pemerintah nonstruktural yang bersifat mandiri dan bertanggung jawab kepada Presiden melalui Menteri. BAZNAS merupakan lembaga yang berwenang melakukan tugas pengelolaan zakat secara nasional. Untuk membantu BAZNAS dalam pelaksanaan pengumpulan, pendistribusian, dan pendayagunaan zakat, masyarakat dapat membentuk Lembaga Amil Zakat (LAZ). LAZ wajib melaporkan secara berkala kepada BAZNAS atas pelaksanaan pengumpulan, pendistribusian, 
dan pendayagunaan zakat yang telah diaudit syariat dan keuangan.

Salah satu yang menunjang kesuksesan manajemen zakat dalam merealisasikan tujuan kemasyarakatan adalah pendistribusian dan penerapan yang baik. Hal pertama dalam penyaluran zakat adalah dengan melakukan distribusi lokal atau dengan kata lain lebih mengutamakan zakat yang berada dalam lingkungan terdekat lembaga zakat, dibandingkan penyaluran untuk wilayah lainnya, hal ini disebut juga sebagai "centralistic" atau hubungan dengan lingkungan sekitar. Selain itu pengendalian intern badan penyaluran zakat juga sangat mempengaruhi kesuksesan manajemen zakat.

Menurut Mulyadi (2013) menyatakan bahwa pengendalian intern adalah bagian dari sistem yang meliputi struktur organisasi, metode dan ukuran-ukuran yang dikoordinasikan untuk menjaga kekayaan organisasi, mengecek ketelitian dan keandalan data akuntansi, mendorong efesiensi dan mendorong dipatuhinya kebijakan manajemen.

Tujuan dari sistem pengendalian intern itu sendiri yang menurut Mulyadi (2013) dibagi menjadi dua macam yaitu : (1) Pengendalian Intern Akuntansi, meliputi struktur organisasi, metode dan ukuran-ukuran yang dikoordinasikan terutama untuk menjaga kekayaan organisasi dan mengecek ketelitian dan keandalan data akuntansi. Pengendalian intern akuntansi yang baik akan menjamin kekayaan para investor dan kreditur yang di tanamkan dalam perusahaan yang akan menghasilkan laporan keuangan yang dapat dipercaya. (2) Pengendalian Intern Administratif meliputi metode, dan ukuran-ukuran yang dikoordinasikan terutama untuk mendorong efesiensi dan dipatuhinya kebijakan manajemen.

\section{METODE PENELITIAN}

Penelitian dilaksanakan di kantor BAZNAS Sulawesi Selatan yang bertempat di Jalan Mesjid Raya No. 55, Baraya, Bontoala, Kota Makassar, dan dilakukan dari bulan April sampai dengan Mei 2017. Adapun jenis data yang digunakan dalam penelitian ini menggunakan data kualitatif dan kuantitatif. Data kualitatif diperoleh dengan cara mengadakan observasi secara langsung di lokasi dan wawancara dengan pimpinan, serta staf dan karyawan BAZNAS Sulawesi Selatan yang terkait dengan keperluan informasi untuk memperoleh data yang akurat. Data kuantitatif diperoleh dari dokumen laporan penerimaan, pengeluaran dana kas pada BAZNAS Sulawesi Selatan serta arsip-arsip pada BAZNAS Sulawesi, serta dokumen-dokumen BAZNAS pusat.

Pengolahan data dilakukan dengan metode analisa secara kualitatif yaitu analisis deskriptif yang menekankan pada pemahaman mengenai pengendalian intern yang dilakukan dalam penerimaan dan penyaluran dana ZIS pada BAZNAS Sulawesi Selatan. Secara kompleks dan rinci yang sifatnya menjelaskan secara uraian dalam bentuk kalimat

\section{HASIL PENELITIAN DAN PEMBAHASAN}

Masyarakat Sulawesi Selatan yang mayoritas umat islam memiliki potensi zakat yang sangat besar namun potensi ini belum dimanfaaatkan dan dikelola secara terpadu dan optimal. Bahkan pelaksanaannya masih banyak dikelola secara individual, oleh karena itu dibentuklah BAZNAS sebagai suatu badan yang bertugas untuk mengelola dana zakat secara berencana di wilayah Sulawesi Selatan.

BAZNAS Sulawesi Selatan yang bertugas mengkoordinir, mengumpulkan dan mengawasi pelaksanaan zakat serta menyalurkannya kepada mustahik menurut 
ajaran islam dalam wilayah Provinsi Sulawesi Selatan dan untuk mencapai maksud dan tujuan tersebut maka dibentuk BAZNAS ditiap desa/kelurahan, kecamatan, kabupaten/kota dan lembaga-lembaga pemerintah maupun swasta dan wilayah Provinsi Sulawesi Selatan.

Dengan adanya pembentukan BAZNAS pada setiap desa/kelurahan sampai dengan tingkat kabupaten/kota tersebut maka teknis pengumpulan dana penyaluran dikelola langsung oleh yang dibentuk tersebut. Dalam artian bahwa BAZNAS Sulawesi Selatan hanya menerima laporan secara administrasi dari yang dibentuk tersebut tentang hasil pengelolaan dana zakat, infaq, dan shadaqah pada wilayahnya dan kemudian dana zakat, infaq, dan shadaqah pada Provinsi Sulawesi Selatan merampungkan laporan tersebut dan setelah itu disosialisasikan kepada masyarakat tentang hasil pengelolaan dan zakat, infaq, shadaqah tersebut.

Disamping kegiatan tersebut BAZNAS Sulawesi Selatan mempunyai kegiatan dengan melakukan sosialisasi yang sesuai dengan UU Nomor 23 Tahun 2011 kepada semua instansi pemerintah atau swasta DPRD, BUMN tingkat Provinsi dan masyarakat umum, merencanakan strategi pengumpulan zakat, mendistribusikan zakat dengan prestasi $30 \%$ konsumtif, dan $70 \%$ produktif serta mempersiapkan perlengkapan administrasi berupa formulir Nomor Pokok Wajib Zakat (NPWZ), Bukti Setor Zakat (BSZ) dalam rangka memperlancar pengelolaan dana zakat, infaq, dan shadaqah yang terdiri dari empat rangkap yang akan diterima oleh muzakki, tempat penyetoran, BAZNAS Sulawesi Selatan, dan Arsip Pajak.

Dalam mempermantap mekanisme kerja menyebarluaskan penghayatan dan pengamalan masyarakat mengenai BAZNAS dan zakat serta untuk mengidentifikasi pengumpulan zakat, infaq, dan shadaqah. Maka BAZNAS juga mengadakan pertemuan berupa orientasi pelaksanaan zakat, infaq, dan shadqah dengan menghadirkan muballiq dan pengurus BAZNAS.

Dengan adanya surat keputusan gubernur Provinsi Sulawesi Selatan Nomor 420 tahun 2011 tentang pengurus BAZNAS maka BAZNAS Sulawesi Selatan sebagai salah satu bentuk usaha yang bertugas mengelola dana zakat. maka untuk mempermudah pengelolaan dananya BAZNAS Sulawesi Selatan memberikan atau melimpahkan kewenangan BAZNAS Daerah untuk melaksanakan operasional kegiatan pengumpulan dan penyaluran dana zakat tersebut di wilayahnya masing-masing agar pengelolaanya dapat dilakukan dengan maksimal sehingga dapat berdaya guna dan berhasil guna.

Setelah BAZNAS di tingkat daerah melakukan kegiatan operasional pengumpulan dan penyaluran dana zakat, maka BAZNAS di daerah-daerah dalam hal ini BAZNAS kabupaten/kota menyusun laporan pertanggungjawaban tentang pengelolaan dana zakat diwilayahnya masing-masing baik dalam bentuk pengumpulan maupun penyalurannya kepada yang berhak menerimanya. BAZNAS Provinsi Sulawesi Selatan menerima hasil laporan pertanggungjawaban kabupaten/kota madya setelah itu BAZNAS Sulawesi Selatan merampungkan hasil-hasil tersebut dengan membuatkan laporan tentang realisasi pengumpulan dan penyaluran dan zakat Sulawesi Selatan dan untuk selanjutkan dikirim kepada daerah tingkat II dan ketua-ketua BAZNAS sekabupaten/kota Sulawesi Selatan.

Untuk mencegah tidak terjadinya penyimpangan progran dalam suatu organisasi, maka pengawasan dilakukan denga cara pemantauan, pengawasan internal dan eksternal. Pengawasan internal dilakukan oleh dewan pertimbangan dan komisi pengawas yang dibentuk, sedangkan pengawasan eksternal oleh pengawas pemerintah. Pemantauan dan pengendalian 
dilakukan oleh pemerintah yaitu dengan cara mengirim laporan pelaksanaan tugas dan pengelolaannya dalam bentuk pertanggungjawaban BAZNAS Provinsi dan Kabupaten/Kota selama satu periode kepada Gubernur dan Kantor Wilayah Kementerian Agama Provinsi Sulawesi Selatan. Adapun sistem prosedur dalam penerimaan dan penyaluran dana ZIS pada BAZNAS dapat dilihat pada Gambar 1.

Berdasarkan sistem akuntansi biaya penerimaan dan panyaluran dana ZIS disertai flowchart (Gambar 1), tanpak tidak adanya pemisahan tugas antara bagianbagian yang ada. Dalam artian bahwa sekretariat bertindak sebagai penerima sekaligus melakukan pencatatan, oleh karena itu untuk menghindari hal-hal yang bisa menimbulkan kecurangan perlu adanya

\section{$\underline{\text { Sekertariat }}$}

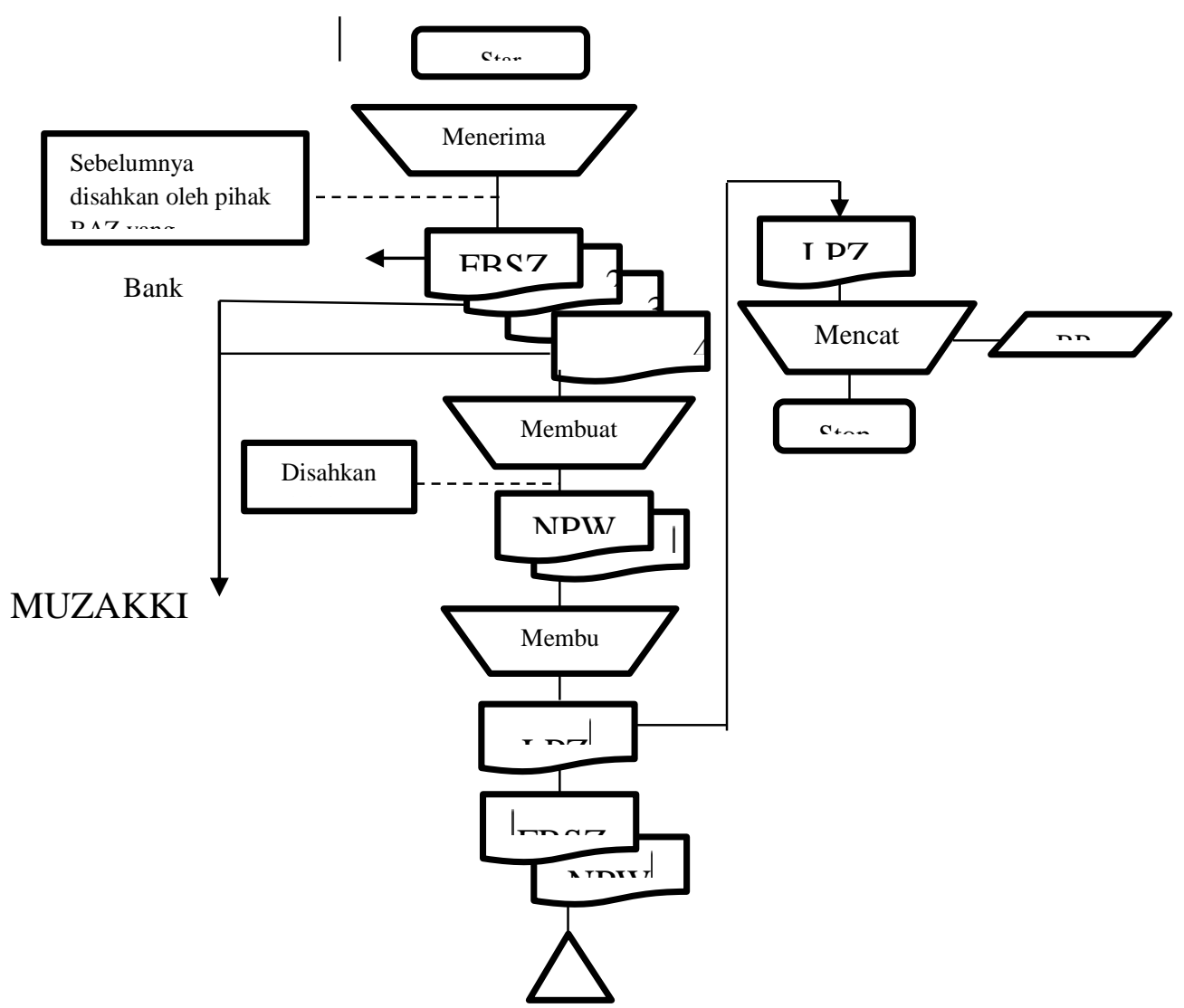

Gambar 1. Sistem dan Produser Penerimaan Dana ZIS. FBSZ

(Formuli Bukti Setor Zakat), DPZ (Daftar Penerimaan Zakat), BPK (Buku Penerimaan Kas), NPWZ (Nomor Pokok Wajib Zakat) pembagian job dalam hal pengelolaan keuangan yakni penerima orang tersendiri, dan pencatatan tersendiri sehingga dalam struktur organisasi perlu ditambahkan bagian akuntansi.

Selanjutnya dalam pengumpulan dan penyaluran dana ZIS telah disediakan formulir, namun formulir yang digunakan untuk pengumpulan dana ZIS tidak dirangkap dibagian terkait, dan tidak adanya formulir penerimaan dan pengeluaran kas. Hal ini jika dipraktekkan, bisa juga dapat menimbulkan manipulasi data, karena hanya satu bagian yang memegang bukti tersebut. Oleh karena itu dalam hal pengumpulan dana zakat formulir tersebut harus dirangkap dan dibagikan kebagian-bagian yang terkait, sehingga mudah diawasi.

\section{$\underline{\text { Bendahara }}$}


Pengawasan terhadap pengelolaan dana zakat telah dilaksanakan berdasarkan UU Nomor 23 Tahun 2011. Untuk melihat pengendalian intern dalam BAZNAS Sulawesi Selatan, dapat dilihat dari hasil wawancara yang telah dilakukan kepada pihak-pihak yang bertanggungjawab dan yang berwenang dalam BAZNAS Sulawesi Selatan. Adapaun hasil wawancara yang kami dapatkan dari parah karyawan dan staf BAZNAS Sulawesi Selatan.

Menurut DR. dr. H. Muh. Khidri Alwi, M. Kes (Wakil Ketua III BAZNAS Sulawesi Selatan), Pengendalian Intern BAZNAS Sulawesi Selatan sudah tersusun dengan baik, semua karena ada lima orang komsioner itu memiliki proporsi masing-masing, ketua umum dibantu oleh dengan empat ketua. Yaitu ketua 1 (bagian pengumpulan), ketua 2 (bagian pendistribusian), ketua 3 (bagian pelaporan), dan ketua 4 (bagian human). Keempat ketua melakukan proporsi masingmasing dan membuat program masingmasing. Beliau juga mengemukakan Pengendalian Intern BAZNAS Seulawesi Sealatan telah berjalan sesuai dengan sistem prosedur yang telah dibuat oleh BAZNAS Sulawesi Selatan, karena telah dilakukan paripurna, semua pengurus baru semuanya memulai proporsi masing-masing apa yang harus dilakukan. Prosedur dilakukan berdasarkan pedoman struktur apa yang dilakukan oleh BAZNAS Pusat, itulah juga yang BAZNAS Sulawesi Selatan. Berdasarkan empat ketua itu, mereka harus bekerja dengan apa yang mereka buat, menyamakan program yang berbedah tetapi tujuannya tetap sama.

Pengendalian intern pada BAZNAS Sulawesi Selatan sudah berjalan sesuai dengan UU Nomor 23 Tahun 2011. Telah sesuai karena UU harus dijalankan mulai pasal 1 sampai dengan 36, dengan keluarnya peraturan pemerintah 14 tahun 2014 sebagai pedoman pelaksanaan UU ini, dan keluar inpres semua lembaga-lembaga negara itu harus diundang-undangkan. Berdasarkan Pedoman UU 23 Tahun 2011 pengurusan BAZNAS harus dilakukan ship improfonted karena itu dibahasakan oleh undang-undang. Adapun Yang dilakukan oleh pimpinan BAZNAS Sulawesi Selatan jika karyawan dan staf tidak menjalankan peraturan dan kebijakan sistem pengendalian intern yang sudah ditetapkan yaitu, mengistrusikan langsug kepada semua karyawan apa yang harus dilakukan.

Rasmudin (Kepala Sekretariat BAZNAS Sulawesi Selatan) menjelaskan bahwa Peranan PSAK 109 BAZNAS Sulawesi Selatan belum di aplikasikan karena BAZNAS Sulawesi Selatan masih menggunakan cara manual. Bakri, SE. I (Staf BAZNAS Sulawesi Selatan bagian Administrasi) menjelaskan hal yang sama bahwa, Peranan sistem akuntansi dalam hal ini belum diaplikasikan pada BAZNAS Seulawesi Selatan karena masih menggunakan cara manual dan belum diatur oleh PSAK 109. Beliau juga menjelaskan bahwasanya Pengumpulan dana ZIS sudah dijalankan dengan baik oleh karyawan yang bertanggungjawab. Rusman (Staf BAZNAS Sulawesi Selatan bagian Administrasi) mengatakan bahwa sistem pengendalian intern pada penerimaan dana ZIS yaitu langsung dan tidak langsung dan sistem pencatatan Sistem pencatatan laporan penerimaan dana ZIS yaitu List, Print rek koran laporan BAZNAS perbulan, dan Rekap.

Komaruddin, S. Ag (Staf BAZNAS Sulawesi Selatan bagian Pendistribusian) mengatakan bahwa peranan sistem akuntansi pengeluaran kas dalam hal ini belum diaplikasikan pada BAZNAS karena masih menggunakan cara manual dan belum diatur oleh PSAK 109, dalam pendistribusian dilakukan oleh semua karyawan. Rasmudin (Kepala Sekretariat BAZNAS Sulawesi Selatan) menjelaskan bahwa Sistem 
pelaporan pada BAZNAS Sulawesi Selatan pertama-tama dirapatkan guna melihat berapa penerimaan dana ZIS, melihat sesuai dan tidak kesesuaian kemudian proposal. Komaruddin, S. Ag (Staf BAZNAS Sulawesi Selatan bagian Pendistribusian) mengatakan bahwa sistem pengendalian intern pada BAZNAS Sulawesi Selatan sudah berjalan dengan baik dan penyalurannya selalu di survei oleh staff dan karyawan. Putri Maharani Mutiara dan Nur Safinah Dewi (Muztahik), mengemukakan pendapatnya tentang BAZNAS Sulawesi Selatan. BAZNAS Sulawesi Selatan sangat bermanfaat bagi masyarakat, karena masyarakat yang tidak mampu akan dibantu oleh BAZNAS Sulawesi Selatan. Contohnya saja BAZNAS Sulawesi Selatan telah mendirikan sekolah tanpa adanya pungutan biaya sama sekali. beliau juga sudah berkali-kali menerima dana ZIS beberapa kali sampai-sampai dia sendiri tidak bisa menghitungnya.

Dari hasil wawancara diatas dapat diketahui bahwa pengendalian intern pada pencatatan pelaporan penerimaan dan pengeluaran dana ZIS masih menggunakan cara manual dan belum di atur oleh PSAK 109. Namun ketertiban di BAZNAS Sulawesi Selatan sudah tersusun dengan baik karena ketua umum dibantu oleh empat ketua dengan proporsi masing-masing dengan program

\section{DAFTAR PUSTAKA}

Atyanto Mohatmyo, S.E., M.M., AK, 2014. Sistem Informasi Akuntansi Suatu Pengantar. Yogyakarta : Deepublish.

Adhadi, I., Kertahadi, dan Siti R. H., 2015. Evaluasi Sistem Pengendalian Intern Atas Penerimaan Zakat, Infaq dan Sedekah (Studi Pada Yayasan Dana Sosial Al Falah (YDSF) Malang). 28 (2): 4-5.

Ghufraanaka, Dina F. S., 2016. Pengakuan, Pengukuran, Penyajian, dan yang berbedah-bedah tetapi tujuannya tetap sama. Kegiatan BAZNAS dilapangan tidak langsung di tinjau oleh karyawan, karena BAZNAS Sulawesi Selatan memiliki badan penanggulangan bencana yang langsung turun kelapangan dan memberikan informasi kepada staf dan karyawan BAZNAS Sulawesi Selatan

\section{KESIMPULAN}

Hasil penelitian menjelaskan bahwa pengendalian internal BAZNAS Sulawesi Selatan terhadap penerimaan dana Zakat, Infaq, dan Shadaqah (ZIS) secara keseluruhan telah diterapkan dengan baik berdasarkan UU Nomor 23 Tahun 2011. Dan masih menggunakan sistem prosedur manual dan belum menerapkan PSAK 109.

BAZNAS Sulawesi Selatan memiliki kelebihan dan kendala yang dihadapi dalam pengendalian intern. Kelebihan BAZNAS Sulawesi Selatan berdasarkan hasil observasi karyawan dan parah muzakki menyatakan sistem prosedurnya sudah tertata dengan baik. Kendala yang dihadapi oleh BAZNAS Sulawesi Selatan adalah masih menggunakan cara manual sehingga butuh proses untuk beradaptasi dengan ketidaksesuainnya dengan PSAK 109

Pengungkapan Aset Kelolaan Pada Lembaga Amil Zakat. 3 (5): 381-385.

Istutik, 2013. Analisis Implementasi Akuntansi Zakat dan Infak/Sedekah (PSAK:109) Pada Lembaga Amil Zakat Di Kota Malang. 2 (10): 22.

Irham Fahmi, 2014. Perilaku Organisasi : Teori, Aplikasi, dan Kasus. Bandung.: Penerbit Alfabeta.

Kementerian Agama RI Direktorat Jenderal Bimbingan Masyarakat Islam 
Direktorat Pemberdayaan Zakat, 2015. Membangun Peradaban Zakat Nasional. Jakarta.

Kementerian Agama RI Direktorat Jenderal Bimbingan Masyarakat Islam Direktorat Pemberdayaan Zakat, 2015. Standarisasi Amil Zakat di Indonesia. Jakarta.

Kementerian Agama RI Direktorat Jenderal Bimbingan Masyarakat Islam Direktorat Pemberdayaan Zakat, 2015. Panduan Pengembangan Usaha bagi Mustahik. Jakarta.

Kementerian Agama RI Direktorat Jenderal Bimbingan Masyarakat Islam Direktorat Pemberdayaan Zakat, 2015. Komplikasi Peraturan dan Standar Pengawasan Umum Lembaga Zakat. Jakarta.

Kementerian Agama RI Direktorat Jenderal Bimbingan Masyarakat Islam Direktorat Pemberdayaan Zakat, 2015. Manajemen Pengelolaan Zakat. Jakarta.

M Nur R. Al A. 2011. Efek Multiplier Zakat Terhadap Pendapatan di Provinsi Dki Jakarta. Ikatan Ahli Ekonomi Islam Indonesia 4 (1): 56-64.

Muhammad A., S. 2013. Zakat Infaq, Dan Sedekah : Modal dan Model Ideal Pembangunan Ekonomi dan Keuangan Modern. 5 (2): 273.
Nurul H., Abdul G., 2012. Analisis Intensi Muzakki Dalam Membayar Zakat Profesi.4 (2): 225.

Rahman, P. 2013. Pengantar Akuntansi 1: Pendekatan Siklus Akuntansi. Jakarta: Penerbit Erlangga.

Sugiyono. 2011. Metode Penelitian Pendidikan Pendekatan Kuantitatif, Kualitatif, dan $R$ dan $D$. Bandung: Alfabeta.

Sabrina, S. 2015. Penerapan Psak No. 109 Tentang Pelaporan Keuangan Akuntansi Zakat, Infaq/Sedekah Pada Badan Amil Zakat Provinsi Sulawesi Utara. 3 (4): 318-319.

Siti, M. W. dan Siska P. U. 2015. Analisis Pengendalian Intern Coso Pada Pengelolaan Dana Zakat, Infaq, dan Shadaqah (ZIS). Journal of Social Science And Religion. 22 (2): 232-233.

Tika, W., S. Rosyidi. 2015. Model Pendayagunaan Zakat Produktif Oleh Llembaga Zakat Dalam Meningkatkan Pendapatan Mustahiq. 1(1): 94-97.

Yulianarti, L. A. F. Ekaningsih, dan A. Roziq. 2012. Akuntabilitas Lembaga Pengelola Zakat di Kabupaten Jember. Jurnal CBAM-FE. 1(1): 1193-1212. 